DOI: https://doi.org/10.47405/mjssh.v6i3.715

\begin{tabular}{|c|c|}
\hline & Malaysian Journal of Social Sciences and Humanities (MJSSH) \\
\hline 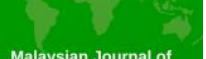 & Volume 6, Issue 3, March 2021 \\
\hline Humanities & e-ISSN : 2504-8562 \\
\hline & $\begin{array}{l}\text { Journal home page: } \\
\text { www.msocialsciences.com }\end{array}$ \\
\hline
\end{tabular}

\title{
A Framework of the Energy-Efficient Vehicle Initiative and its Implementation in a Developed Country: the case of Malaysia
}

\author{
Farrah Effa Daud ${ }^{1}$, Zakiah Ponrahono', ,A.A. Fatiah ${ }^{1}$, Syakir Amir Ab Rahman², Syazwani \\ Sahrir ${ }^{1}$ \\ ${ }^{1}$ Department of Environment, Faculty of Forestry and Environment, Universiti Putra Malaysia (UPM) \\ ${ }^{2}$ Kulliyyah of Architecture and Environmental Design, International Islamic University Malaysia (IIUM) \\ Correspondence: Zakiah Ponrahono (zakh@upm.edu.my)
}

\begin{abstract}
Energy-Efficient Vehicles (EEV) are a form of green transportation that minimise carbon dioxide emissions and eliminate reliance on fossil fuels. As an oil-producing nation, Malaysia needs to conserve its resources and alternate its dependence on fuel combustion engines and their toxic emissions. In recent years, Malaysia has set EEV production goals and adopted several policies to reduce greenhouse gas emissions while meeting the transportation sector's growing energy demands. This study evaluates the current policies and initiatives for EEV and their relevance and implementation in the present scenario. It is worth ascertaining the critical elements that need to be in place for the government to push for the adoption of EEV. This study first reviewed relevant government policies supporting EEVs. Next, a comparative analysis of EEVs initiatives between AsiaPacific Economic Cooperation countries was discussed. Simultaneously, expert panels were consulted through interview sessions to identify gaps in the implementation of EEVs. Based on the findings, the relationship framework of EEVs initiatives and an outline of strategies to improve existing practices were formulated. As a result, this study proposed integrating various agencies and market players as an essential factor to determine the success of implementing EEVs. By way of conclusion, a summary of effective policies is put forward as a recommendation to stimulate the current EEV market. This study sets the stage for policymakers to adopt and improve EEV strategies.
\end{abstract}

Keywords: government policy, energy-efficient policy, policy mechanisms, transportation policy framework

\section{Introduction}

Climate change and Greenhouse Gas (GHG) emissions have emerged as the most challenging environmental problem in recent years. Ritchie \& Roser (2017) found that greenhouse emissions have risen significantly since the year 1961, and in 29 years, the temperature of the earth's surface increased by approximately 0.8 degrees. The transportation sector uses up to $27 \%$ of global energy and contributes to GHG emissions (Shukor et al., 2017). Continuous growth in energy demand, compounded by the instability of oil prices and fuel subsidies, has set the transport sector on the road to an unsustainable fuel situation that poses a threat to national energy security. Furthermore, the conventional motor vehicle operates using an Internal Combustion Engine (ICE) that runs on fossil fuels such as petrol or diesel (Shukor et al., 2017; Tie \& Tan, 2013). In Malaysia, the "Green Technology Master Plan" in 2017 reported that Malaysia's transport system consumed the highest 
amount of energy, with an increase from 37\% in 1993 to 43.3\% in 2013 (Ministry of Energy Green Technology and Water (KeTTHA), 2017).

The increase in energy consumed has increased carbon dioxide $\left(\mathrm{CO}_{2}\right)$ emissions significantly. It has placed Malaysia third in ranking after Indonesia and the Philippines in terms of $\mathrm{CO}_{2}$ emissions from the transportation sector among the Association of South-East Asian Nations (ASEAN) countries (KeTTHA, 2017). In 2014 alone, reports show that the transport sector emitted about 63,020 Gigagram (GG) of $\mathrm{CO}_{2}$ (Ministry of Energy, Science, Technology, Environment and Climate Change (MESTECC), 2018).

Given that this is a global trend reducing $\mathrm{CO}_{2}$ emissions from the transport sector has become a global agenda. Due to concerns over energy security and global climate change, governments are moving towards adopting electric vehicles to create a more sustainable transportation system (Nie et al., 2016). One of the Malaysian government's measures in reducing GHG emission for the transport sector is developing and utilising EEV as part of a mitigation plan (Ministry of Natural Resources and Environment Malaysia (KeTSA), 2015).

\section{Implementation of EEV in Malaysia}

The global trend is to adopt electric vehicles. However, Malaysia is heading in a different direction by looking towards EEV (KeTTHA, 2017). The Malaysian government has introduced the EEV programme under the National Automotive Policy 2014 (NAP 2014), which promotes the manufacturing and sales of EEV (Ministry of International Trade and Industry (MITI), 2014). This programme dictates the growth of the automotive sector. According to this policy, Malaysia inspires to be the hub for EEV in ASEAN by the year 2020. Additionally, the National Automotive Policy (NAP) 2020 acts as a NAP 2014 enhancement, in which three directions (technology and engineering, investment, and market expansion) and strategies were formulated (Malaysia Automotive Robotics and IoT Institute (MARii), 2020). The NAP 2014 policy defined EEV as any vehicle that meets a set of specifications related to carbon emission levels and fuel consumption.

Table 1: Target and current achievement related to EEVs

\begin{tabular}{|c|c|}
\hline Target & Achievement \\
\hline $\begin{array}{l}\text { Year: Projected number of hybrid } \\
\text { vehicles on the road } \\
-\quad 2020: 108,098 \\
-\quad 2025: 201,484 \\
-\quad 2030: 322,532\end{array}$ & $\begin{array}{l}\text { Year: The number of hybrid vehicles registered } \\
-\quad 2014: 33,350 \\
-\quad 2015: 40,326\end{array}$ \\
\hline $\begin{array}{l}\text { Year: Projected number of electric } \\
\text { vehicles on the road } \\
-\quad 2020: 443 \\
-\quad 2025: 963 \\
-\quad 2030: 1,683\end{array}$ & $\begin{array}{l}\text { Year: The number of electric vehicles registered } \\
-\quad 2014: 75 \\
-\quad 2015: 130\end{array}$ \\
\hline $\begin{array}{l}85 \% \text { of cars produced in Malaysia are } \\
\text { EEV sy } 2020\end{array}$ & $\begin{array}{l}\text { Year: Percentage of total EEV penetration } \\
-\quad 2015: 32.6 \% \\
-\quad 2016: 42.8 \% \\
-\quad 2017: 52 \% \\
-\quad 2018: 63 \% \\
\text { Year: EEV total production volume } \\
-\quad 2016: 247,912 \\
-\quad 2017: 308,807\end{array}$ \\
\hline $\begin{array}{l}\text { Year: Potential emission reduction } \\
\text { from the transport sector }\left(\mathrm{Gg} \mathrm{CO}_{2} \mathrm{eq}\right) \\
-\quad 2020: 157.69 \\
-\quad 2025: 294.23 \\
-\quad 2030: 471.31\end{array}$ & $\begin{array}{l}\text { Year: Emission reduction achieved }\left(\mathrm{Gg} \mathrm{CO}_{2} \mathrm{eq}\right) \\
-\quad 2014: 47.97 \\
-\quad 2015: 61.07\end{array}$ \\
\hline
\end{tabular}


EEV is a vehicle built on a series of specified criteria in terms of carbon emission standards (gram/kilometres $-\mathrm{g} / \mathrm{km}$ ) and fuel usage (I/100km). EEV has negligible if not zero adverse effects on the environment and has the most potent energy and lowest fuel consumption. Potentially, fuelefficient vehicles like Hybrid Electric Vehicles (HEV) or vehicles utilising alternative fuels such as Liquefied Petroleum Gas (LPG), Compressed Natural Gas (CNG), biodiesel, biomass, hydrogen and fuel cells can be defined as EEV (KeTTHA, 2017). Examples of EEV-certified models available in Malaysia include Mazda CX-5 2.0L, Perodua Axia 1.0L, Haval M4, Honda Civic, Volvo XC90, and Renault Zoe. Under the NAP 2014, policymakers and carmakers have been promoting EEV actively as a green vehicle to reduce $\mathrm{CO}_{2}$ emission levels. However, the adoption of EEV depends heavily on how the customer perceives them.

\section{The target and current status of EEV in Malaysia}

The goal was $85 \%$ of automobiles produced in Malaysia are EEVs by 2020 . To date, the Malaysia Automotive, Robotics, and IoT Institute (MARii) reported that the total EEV penetration as of 2018 had reached 62\% and seen as an achievement because the rate has been increasing steadily since 2015 . Based on the Statistical Research Department study on the EEV penetration rate in Malaysia from 2018-2019, it has forecasted to increase from 62\%, or 339,978 units, to $70 \%$ by the end of 2019 (Lye, 2020; Statista, 2019). However, several targets listed in NAP 2014 are still a target for the latest NAP 2020 (Lye, 2020) and can be measured as unmet. Table 1 shows some of the targets and progress of EEVs in Malaysia reported in Third National Communication and Second Biennial Update Report to the United Nations Framework Convention on Climate Change (UNFCC) and MARii.

From 2000 to 2050 , global personal transportation is predicted to rise by $1.7 \%$ annually. Thus, the $13^{\text {th }}$ Sustainable Development Goal on Climate Action has committed the 191 United Nations member states to reduce GHG level, and this can be achieved by incorporating goals in the form of policy at the grassroots level (i.e., national level). Policy and government initiative is the primary enabler to coax consumers to switch to a greener vehicle choice. Pohl \& Yarime (2012) confirmed that in implementing electric vehicles in different countries, the effect of government policies and incentives, as well as regulation, was substantial. For example, to encourage EV adoption, a monetary incentive plan is a crucial tool. For example, the United States federal government and the Chinese government invested billions of dollars in promoting EV adoption (Xiang Zhang et al., 2018). The adoption of EEVs in Malaysia is increasing steadily, but sound future strategies and targets will enable efficient coordination among the policy planners and policy implementers (Adnan, Vasant, Rahman \& Noor, 2016). Coordination is essential to reduce overlapping policies between agencies and avoid any grey areas in policy implementation. It can also provide a clear guideline and a better understanding of key local industry players to better strategies their business and attract more international direct investment to Malaysia. On that basis, the key objectives of this research are:

i. To assess the current policies and initiatives framework related to EEV in Malaysia.

ii. To determine the relevance of the current policy and initiatives in-place.

\section{Methodology}

The research employed qualitative approaches to provide an analytical review of the different facts related to the Malaysian government's strategies and the latest programmes on EEVs. The research framework, as stated in Figure 1, is constructed based on the literature review. Secondary data related to EEVs through authorised documents obtained from various government agencies were analysed. The existing policy and initiatives that support the promotion or adoption of EEVs were extracted through content analysis. In-depth content analysis is adopted using the thematic coding technique, and a deductive approach of qualitative coding data with pre-setup coding schemes derived from the literature review was conducted. The thematic coding is incorporated into legislation/government intervention, economic instruments, infrastructural support, technological support, and human capital development. 
DOI: https://doi.org/10.47405/mjssh.v6i3.715

Figure 1: Research Method Framework

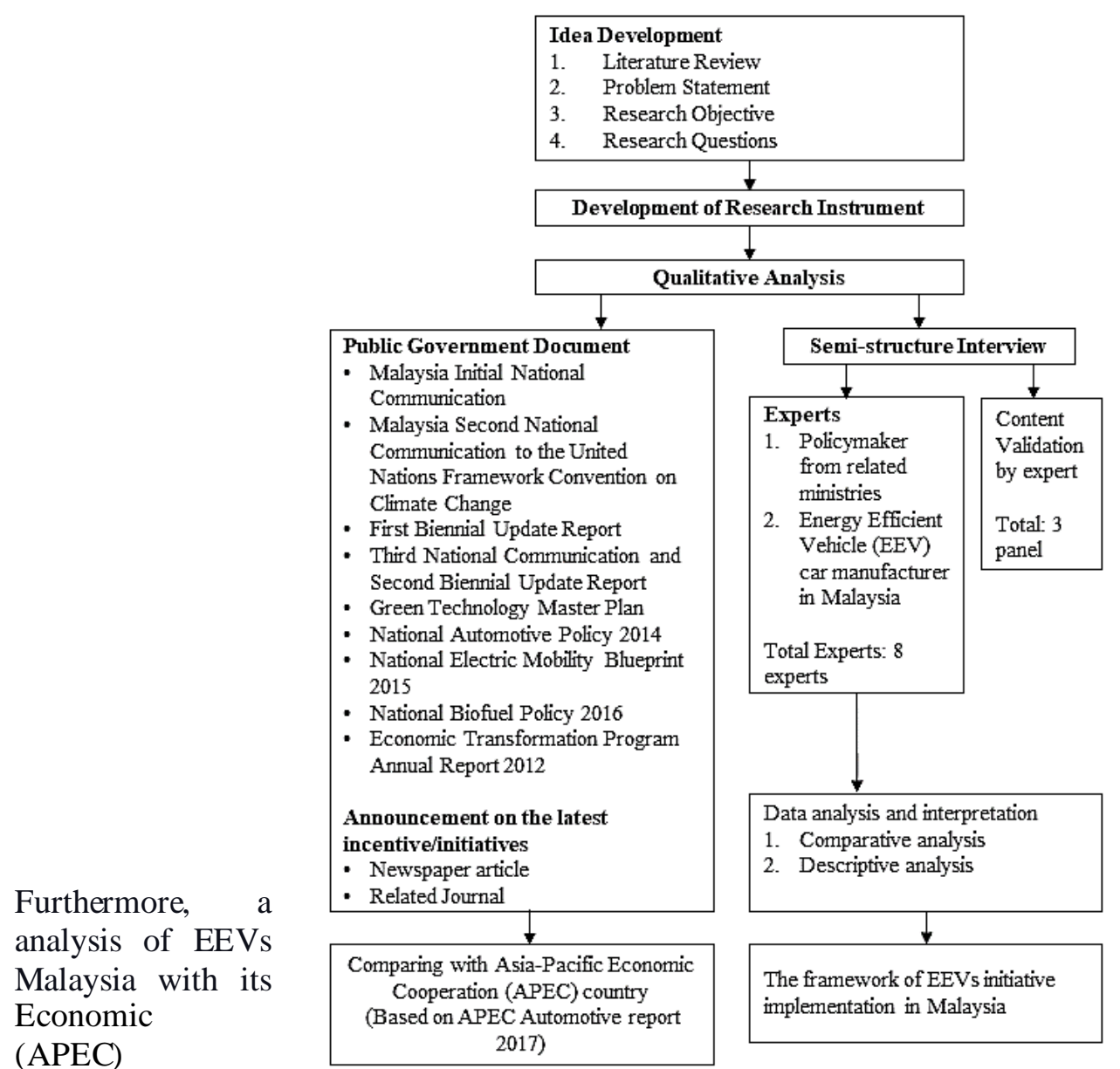

comparative initiatives Asia-Pacific Cooperation counterparts was thematic coding conducted, and was established during the in-depth content analysis. An in-depth discussion was further performed using the data extraction from a semi-structured interview with expert panels to solidify the findings of the primary analyses. This research selects eight (8) experts using a non-probability sampling technique where the characteristic of respondents for the expert semi-structured interview is based on:

i. Policymakers from ministry or agency related to EEV with at least five years' experience

ii. Local car manufacturer

\section{Results and Discussions}

Malaysia's decision to adopt EEVs in its transport policy, including energy-efficient ICE vehicles and hybrid vehicles, is still dependent on fossil fuels, meaning that the green transportation approach remains in its infancy. ICE vehicles are not cleaner than electric vehicles, which means that the definition of EEVs must be updated. Policy-wise, an effort has been made to introduce better variants and engine technology, and cleaner fuel with the introduction of better petrol options, and biofuel with the mission of reducing $\mathrm{CO}_{2}$ emissions in the transport sectors. Chong et al. (2015) highlighted that transport services in Malaysia depend heavily on traditional fossil fuels for vehicles like buses, cars, motorcycles, trains, aeroplanes, vehicles for transportation of goods and marine vehicles. The primary source of direct GHG pollutants is passenger vehicles. Also, passenger cars are significant contributors 
to CO and NOx (Ong et al., 2011). Thus, Malaysia is slowly moving away from the traditional approach by implementing EEVs in its policy.

Malaysia's total car sale reached 604,287 as of September 2019; this confirms the current active demand for passenger vehicles in Malaysia (Table 2). According to Table 1, the adoption of Hybrid Electric Vehicles (HEV) or Plug-In Electric Vehicle (PHEV) targets sales of 108,098 units by 2020, while Battery Electric Vehicles (BEV) estimates a sale of 443 units by the same period. The current statistic shows that as of March 2019, there are only 46,981 PHEVs and 5,403 BEVs currently on the road (Tan, 2019). Thus, the penetration of EEVs is increasing steadily, but the bulk of the volume comes from energy-efficient ICE vehicles.

Table 2: Total vehicles Sales in Malaysia from the Year 2015- September 2019

\begin{tabular}{cccc}
\hline Year & $\begin{array}{c}\text { Passenger Cars } \\
\text { (Units) }\end{array}$ & $\begin{array}{c}\text { Commercial Vehicles } \\
\text { (Units) }\end{array}$ & $\begin{array}{c}\text { Total sales } \\
\text { (units) }\end{array}$ \\
\hline $\mathbf{2 0 1 5}$ & 591,275 & 75,402 & 666,677 \\
$\mathbf{2 0 1 6}$ & 514,594 & 65,491 & 580,085 \\
$\mathbf{2 0 1 7}$ & 514,675 & 61,950 & 576,625 \\
$\mathbf{2 0 1 8}$ & 533,202 & 65,512 & 598,714 \\
$\mathbf{2 0 1 9}$ & 550,179 & 54,108 & 604,287 \\
\hline
\end{tabular}

Source: Malaysian Automotive Association (MAA) (2021)

Hasan-Basri et al. (2019) reported in their findings on EEV usage in Malaysia that $80 \%$ of the respondents are not interested in purchasing EEVs. Thus, consumers are still shying away from hybrid and electric vehicles. The main reason for this appears to be the price point; consumers are not prepared to pay more for the environment over social benefits, which would not benefit them directly in the short term. With limited charging infrastructure and plug-in hybrid vehicles are very expensive to produce, it creates an issue on the lack of tax incentive understanding between private funders (Free Malaysia Today (FMT), 2018). A search at www.carbase.my shows that most hybrid cars cost more than MYR100,000 (MYR 4.12 per USD in 2019). The cheapest variant is Hyundai Ioniq AE HEV Plus (MYR 109,988) while Honda Jazz GK Facelift 1.5 Hybrid (MYR 80,091). The high initial research and development expenditure and high production costs for the battery pack and immature engineering contribute to the high price of some EEVs (Bullard, 2019). Nevertheless, as part of the efforts to raise consumer awareness of EV use, MARii led partnerships with different parties to enable the public to resolve their anxiety about battery range and the cost of restructuring the electromobility lifestyle (Yusof, 2020).

\section{Relationship between policies in differentministries of Malaysia Go vernance}

In Malaysia's governance of EEVs implementation, various agencies are responsible for planning and monitoring the implementation. Figure 2 shows the integration of agencies in EEVs implementation in Malaysia. Under NAP 2014, a significant focus is on various policies and legislation that need to be implemented to push for the adoption of EEVs. NAP 2014 focuses on reducing carbon emissions, promoting EEVs and establishing Malaysia as the ASEAN EEV hub by 2020. The policy defines strategic investments and technological upgrading for the execution in the regional hub and to develop it according to the international standards by the year 2020. The standard includes vehicles' classification in 14 different categories, each having a unique set of specifications and is assessed using the UN ECE R101 standard. The Malaysian government also proposes investments in green automotive technologies to develop the domestic automotive sector to encourage the EEV movement. NAP 2014 mainly focuses on the automotive industry as a whole, and it is governed by the Ministry of International Trade and Industry (MITI) and MARii.

The NAP 2014 alone is not enough to support EEVs in Malaysia; this is especially true because hybrid and electric vehicles are still considered new in Malaysia. Knowing this, the Ministry of Energy, Science, Technology, Environment, and Climate Change (MESTECC) and its lead agency, the 
DOI: https://doi.org/10.47405/mjssh.v6i3.715

Malaysian Green Technology Corporation (MGTC) produced the National Electric Mobility Blueprint 2015 (NEMB 2015). This policy focuses on developing electric mobility in Malaysia to position the nation at a top rank in the electronic mobility market. The policy focuses on strengthening the electric mobility ecosystem and charging infrastructure while accelerating the electric mobility technology localisation opportunities. This policy includes all EVs in Malaysian markets, which range from HEVs, using fossil fuels and battery without external charging, plug-in hybrid EVs (PHEVs running on both fossil and battery fuel while allowing external charging) and Battery EVs (BEVs running on battery only). For personal vehicles, some of the available variants are as Table 3 depicts.

Table 3: Some of the EVs variants available in Malaysia (Ministry of Energy Green Technology and Water (KeTTHA), 2017)

\begin{tabular}{cc}
\hline Electric vehicle type & Variants available in Malaysia \\
\hline HEV & Toyota Prius, Honda Jazz \\
PHEV & BMW 330e \\
BEV & Nissan Leaf, Tesla Roadster \\
\hline
\end{tabular}

To support the transport sector's energy demand, the Malaysian government put forward the National Biofuel Policy through the Ministry of Primary Industries (MPI). Biofuel is an alternative fuel source. Biodiesel based on the palm is a combination of Palm Methyl Ester and Petroleum Diesel. This policy aims to support the energy demands of the transport sector by using biodiesel as an alternative fuel source to reduce the dependence on fossil-based fuels while reducing GHG emissions at the same time. The currently available blending is 10 per cent Biodiesel (B10), and the upcoming target is the implementation of 15 per cent Biodiesel (B15). For cleaner energy, the Malaysian government also commenced Euro 4M for RON 97 petrol, which is lower in sulphur content fuels and less vaporisation. These fuels promote more efficient usage and cleaner fuels (KeTTHA, 2017).

It is important to note that the definition of EEVs itself is cross-cutting between ministries; there is no one-policy-feed for all EEVs in Malaysia. The adoption of EEVs needs to be supported by collaboration between ministries and agencies, as explained in Figure 2. Furthermore, as part of the nation's obligations to the international body, Malaysia reports the total GHG emissions to the United Nations Framework Convention on Climate Change (UNFCC). To date, Malaysia has managed to produce four reports to the UNFCCC.

Figure 2: Summary of the relationship between different policy and ministry's jurisdiction in Malaysia

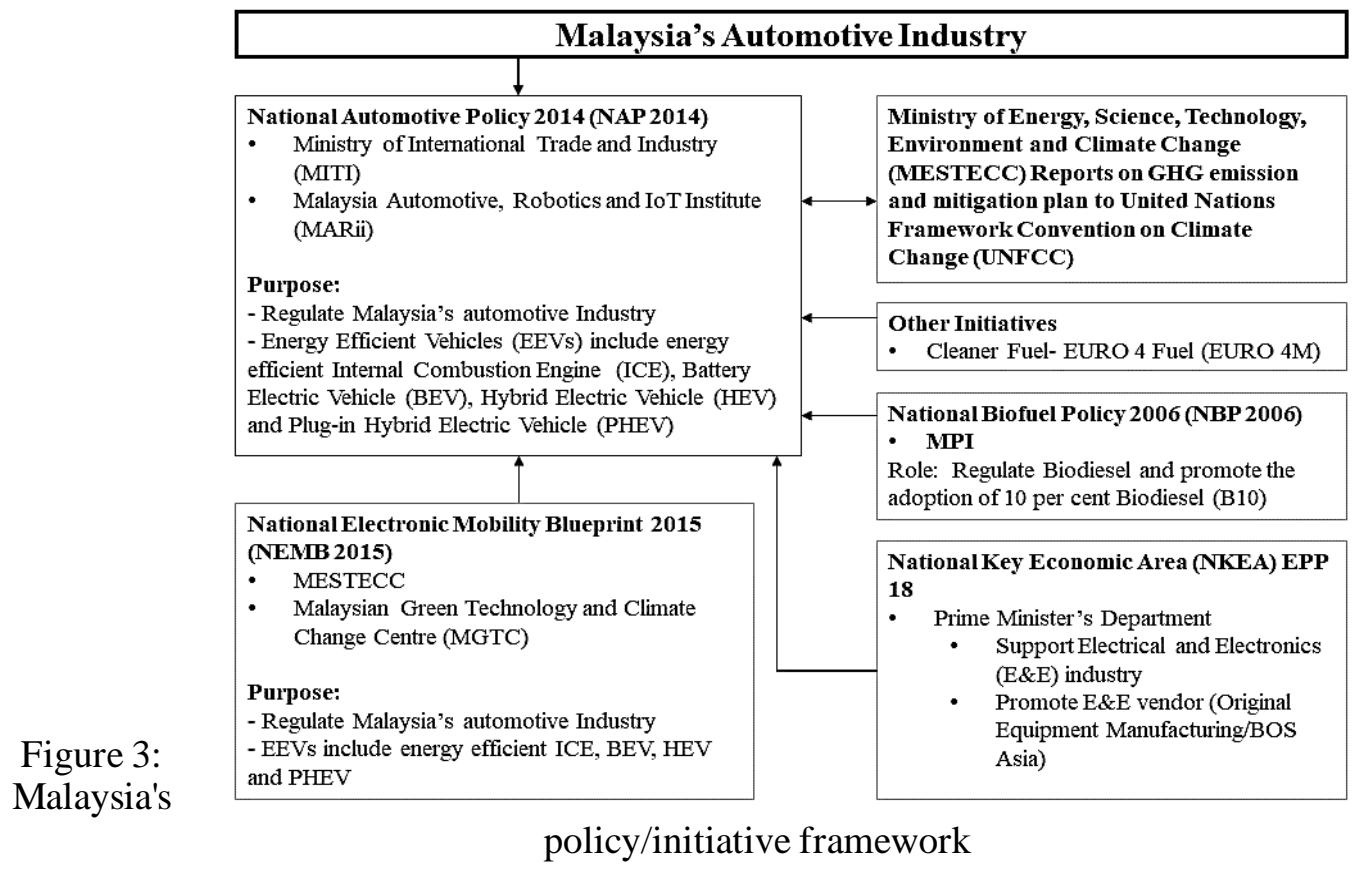




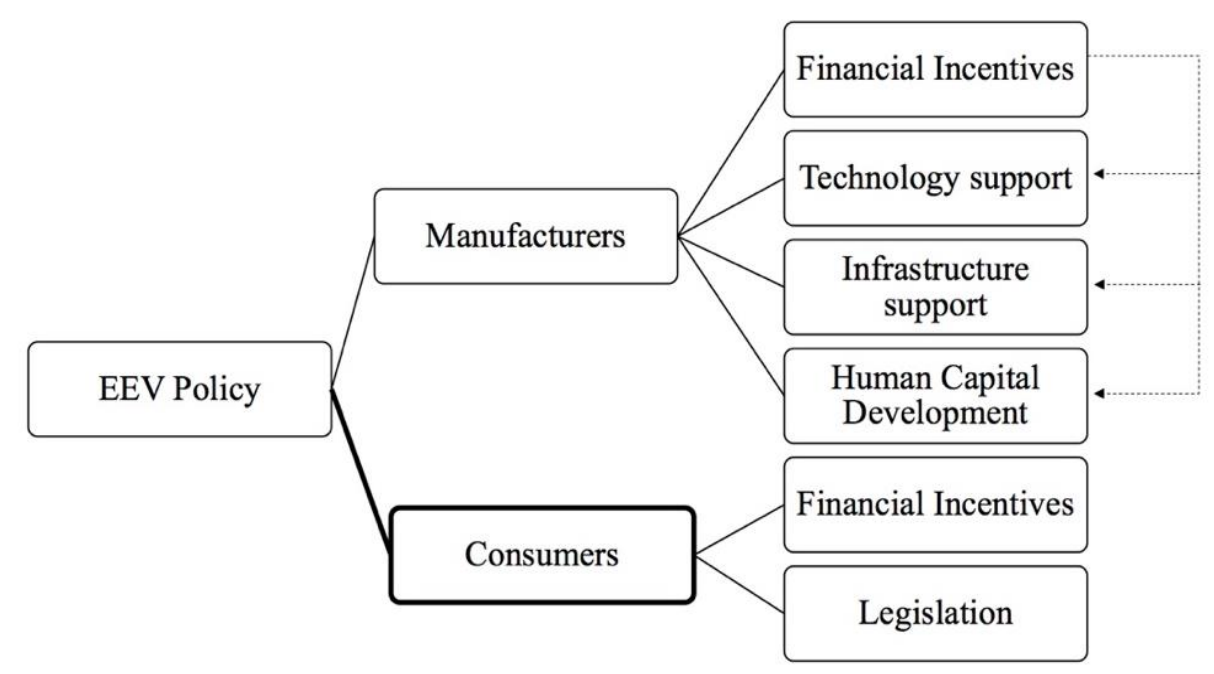

\section{EEV policy framework in Malaysia}

According to Hong et al. (2013), government tax incentives, marketing incentives, and petroleum/diesel subsidy policies are strongly connected to Malaysia's hybrid vehicle adoption. It shows that the role of government policies is vital to support and establish the EEV market. After reviewing all the policies stated above, the government's policies and incentives in Malaysia have been drafted to focus on two targets, manufacturers and consumers. Figure 3 describes that Malaysia's governmental policies were drafted to focus on consumers, the purchaser and manufacturers, the producer. Financial incentives, technology and infrastructure, and human capital development are crucial to support the EEV industry as a whole, while better incentives and legislation will be a determining factor to push the adoption of EEVs among consumers.

\section{Malaysia's financial incentives}

The Malaysian government introduced specific financial incentives to reassure customers that EEVs are both environmentally friendly and economical to encourage its purchase. Furthermore, opportunities are devised to allow producers to keep successfully manufacturing EEVs. The current financial structure for Malaysia is depicted in Figure 4 using Mock \& Zifei (2014) and Xingping Zhang et al. (2014) as a guide. Mock \& Zifei (2014) conducted a study to scrutinise numerous policy incentives involving consumers and categorise them as follows:

i. Direct subsidies (e.g., one-time purchase bonus).

ii. Fiscal incentives (e.g., tax credits, tax cuts, tax exemptions).

iii. Reduction in fuel costs (e.g., incentives due to lower electricity prices than fuel prices due to lower taxation or lower energy costs or both).

There is no direct subsidy in Malaysia for consumers purchasing EEVs nor fuel cost saving incentive. Nevertheless, understanding the need to spur the market, the Malaysian government offers consumers a one-time 100\% import duty and tax exemption for hybrid vehicles from 2010 until 2013. Due to this intervention, the sale of hybrid vehicles increased tremendously. An example of a comparison of price with tax exemption, as Hong et al. (2013) shows, is shown in Table 4.

Unfortunately, the tax exemption only lasted for three years. After the fiscal incentive ended, the sale of hybrid cars had slowed down. To further encourage PHEV and BEV adoption, the Malaysian government recently announced a 50\% reduction on a road tax for the electric and plug-in hybrid vehicle; this is perceived as a positive move to encourage more consumers to make the shift to greener vehicles. Other incentives for consumers include free parking at specialised parking lots in the central 
area, especially in malls. Even though there are many incentives for consumers, middle- and lowermiddle-class Malaysians are still waiting for the opportunity to own a car due to their low purchasing power.

Figure 4. A framework of financial incentives in Malaysia

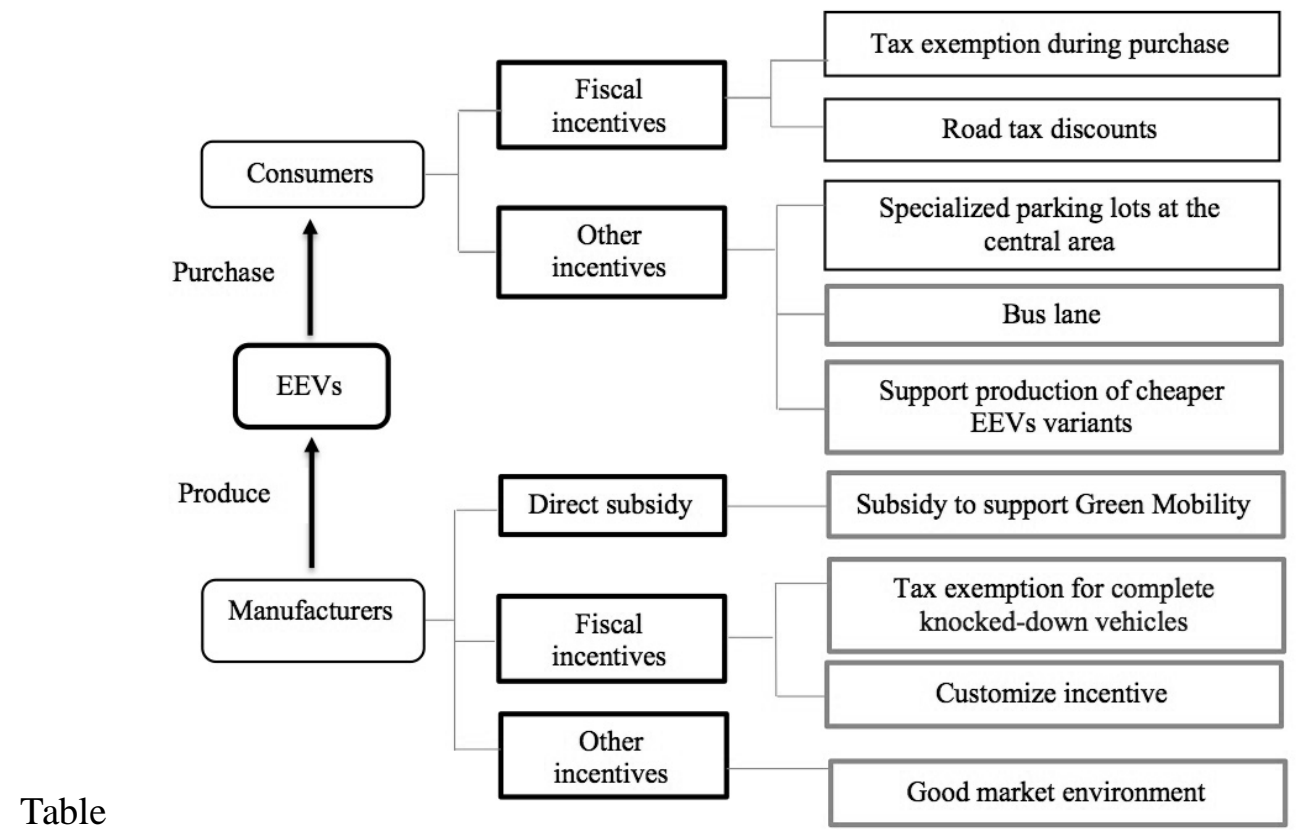

4: Price

comparison with and without tax exemption

\begin{tabular}{cc}
\hline Car type & Honda Civic Hybrid \\
\hline Price without tax exemption & RM162,800 \\
Price with tax exemption & RM120,000 \\
Total difference & RM42,800 \\
\hline
\end{tabular}

Moreover, measures like allowing BEV or PHEV to use bus lanes during peak hours are in the midst of discussion but has yet to be implemented. As one of the efforts to stimulate the sale of EEVs in Malaysia, the government have been encouraging car manufacturers to produce more economical variants of energy-efficient ICE vehicles. Since its release in 2016, a local variant named Perodua Bezza has been the best-selling product in the A-segment (Lye, 2017). Other popular economic EEVs variants include Perodua Myvi, Proton Iriz, Suzuki Alto, and Hyundai i10, to name a few (Ho, 2019). Since EEVs have better fuel economy and cleaner emissions, special tax exemptions will be granted to EEV car manufacturers, and licences will be granted to set up a manufacturing plant in Malaysia. Financial incentives are also given to car manufacturers to provide the right market environment for EEV. Some of the incentives under NAP 2014 include (it is important to note that some of the incentives mentioned below have already ended or will end by the end of 2020):

i. Customised rewards to encourage strategic investments for EEV.

ii. Customised incentives to build crucial strategic areas to improve the domestic automotive ecosystem (including power train, transmission and related control systems, dies and mould foundation, aluminium and other non-ferrous castings).

iii. Completely Knock Down, HEV, PHEV and BEV fuel and excise duty waiver.

iv. $100 \%$ Investment Tax Allowance or Pioneer 10-year status for hybrid and electric vehicle manufacturing. 
v. Sustainable mobility fund to support the development of green mobility

\section{Supportfor technology, infrastructure, and human capital development}

As discussed earlier, the price of EEVs, especially HEVs, PHEVs, and BEVs, is high because of massive research and development spending and the battery pack's high production costs. The cost of EEVs would reduce only through continuous technological processes. Thus, the Malaysian government has prepared incentives to support progressing of Malaysia's relevant technologies. Some of the stimuli and policies are listed below:

i. Ten-year 100 per cent pioneer status and five-year 100 per cent Investment Tax allowance for the production of highly critical or value-added components.

ii. Soft loans for tool, dies, and mould manufacturers to develop new tooling as it can be expensive.

iii. Provision for loans to be grabbed by-product- and spare part suppliers to improve their productivity by strengthening their operations (including management and technical cooperation). Under the Electrical and Electronics (E\&E) Sector 18th Entry Point Project, the National Key Economic Area (NKEA) supports the EEV industry by enabling electric vehicle components manufacturing.

iv. Subsidy to support the research, development, and commercialisation of biofuel technology.

Charging infrastructure is one of the main factors contributing to the adoption of BEVs and PHEVs (Sierzchula et al., 2014). However, such measures often have trouble acquiring funding because large corporations will not invest in infrastructure until a significant scale adoption of the electric vehicle is reached, and consumers would not choose to adopt electric vehicles if there are inadequate charging stations. It is here that government intervention is crucial. The government under the MGTC has introduced and installed electric car charging stations with 330 stations (located at strategic locations such as hotels, shopping malls, and petrol stations) in 227 locations available in Malaysia (Malaysian Green Technology and Climate Change Centre (MGTC), 2021). GreenTech Malaysia, Petronas Dagangan Berhad, and TNB Energy Services Sdn Bhd came together to form a three-way partnership to install EV charging stations. Through cloud-based platforms and mobile applications, registered members will identify the nearest charging stations based on their current locations. The mobile app is essential as it helps members plan a better travel journey.

Currently, there are 6,000 members registered with ChargEV. Income tax exemption is given to property owners who take part in the Green Building Index by installing charging stations, while commercial property owners who decided to install a charging station at their premise will be able to apply for $100 \%$ Green Investment Tax Allowance. The $4^{\text {th }}$ Industrial Revolution is the latest and evolving age in which disruptive technologies and developments like the Internet of Things, robots, Virtual Reality and Artificial Intelligence are transforming the global economy. Realising this, NAP 2014 anticipated the change and emphasised the human capital development in the automotive industry. With the help of Malaysia's Ministry of Education's, the Industry Centre of Excellence was established to balloon the capacity to develop new automotive technology in terms of sub-systems. Other than that, the introduction of an apprenticeship programme aims to accelerate the assimilation in local graduates' domestic automotive industry. MARii is active in organising technical talks with players in the automotive industry to keep them up-to-date on the industry's direction and the latest technology.

\section{Legislation/traffic regulation}

In terms of legislation, there is a tax law stated in NEMB 2015 and The NKEA under the E\&E Sector $18^{\text {th }}$ Entry Point Project, but none of it has materialised as yet. Some of the legislation proposed is:

i. Forming and granting access to low emission zones (areas where traffic is limited)

ii. Emissions based regulations such as zoning and penalties

iii. Carbon emission laws 


\section{Comparison with other APEC countries}

Most developed countries have started producing EEVs that include hybrid, electric and renewable energy, electric and renewable energy, earlier than Malaysia. Global EV Outlook 2019 reported that electric passenger vehicles' global stock had passed 5 million in 2018, increasing about $63 \%$ from the previous year. Out of all the market, China tops the list with $45 \%$ (around 2.3 million) of electric vehicles on the road. Europe comes second, which accounts for $24 \%$ of the global fleet, and the United States of America follows at around 22\%. All these countries have substantial governmental policy measures to support their green mobility. A survey by Lieven (2015), which examines the policy measure of 20 countries in five continents, concluded that the installation of a charging network, high cash grants, or combinations of lower grants with charging facilities is the determining factor in the adoption of BEVs in those countries.

From a comparative analysis between Malaysia and fellow APEC member countries based on the impact of government policy on promoting New Energy Vehicles (NEVs) - The Evidence in APEC Economies (Automotive Dialogue - March 2017), the measures listed in Table 5 can serve as a lesson for Malaysia to learn from other countries in terms of government policy. This comparison might not be a direct comparison to Malaysia, but is an excellent document for comparison as it provides information on what and how our APEC neighbours are doing in term of their EEV policies. All countries except New Zealand started their NEVs policy earlier than Malaysia. Moreover, although Malaysia started introducing EEVs in 2014, Malaysia is not far behind government policy.

Table 5: Description of Regional NEV-Promoting Policy Measures in APEC Countries

\begin{tabular}{|c|c|c|c|c|c|c|}
\hline $\begin{array}{l}\text { Variables/ } \\
\text { Country }\end{array}$ & $\begin{array}{c}\text { Direct } \\
\text { Subsidies }\end{array}$ & $\begin{array}{c}\text { Fiscal } \\
\text { incentives }\end{array}$ & $\begin{array}{l}\text { Inf rastructural } \\
\text { measures }\end{array}$ & Technologies & $\begin{array}{l}\text { Human capital } \\
\text { development }\end{array}$ & $\begin{array}{l}\text { Legislation/ } \\
\text { Traffic } \\
\text { regulation }\end{array}$ \\
\hline $\begin{array}{c}\text { Malaysia } \\
(2014)\end{array}$ & & $\checkmark$ & $\checkmark$ & $\checkmark$ & $\checkmark$ & $\checkmark$ \\
\hline $\begin{array}{l}\text { United } \\
\text { States of } \\
\text { America } \\
\text { (1973) }\end{array}$ & $\checkmark$ & $\checkmark$ & $\checkmark$ & $\checkmark$ & & $\checkmark$ \\
\hline $\begin{array}{l}\text { China } \\
\text { (2009) }\end{array}$ & $\checkmark$ & $\checkmark$ & $\checkmark$ & $\checkmark$ & $\checkmark$ & $\checkmark$ \\
\hline $\begin{array}{l}\text { Australia } \\
\text { (2012) }\end{array}$ & & $\checkmark$ & $\checkmark$ & & & \\
\hline $\begin{array}{c}\text { Canada } \\
(2000)\end{array}$ & $\checkmark$ & & & $\checkmark$ & $\checkmark$ & $\checkmark$ \\
\hline $\begin{array}{l}\text { Japan } \\
\text { (1971) }\end{array}$ & $\checkmark$ & $\checkmark$ & $\checkmark$ & $\checkmark$ & $\checkmark$ & \\
\hline $\begin{array}{l}\text { Korea } \\
\text { (1992) }\end{array}$ & $\checkmark$ & $\checkmark$ & $\checkmark$ & $\checkmark$ & $\checkmark$ & $\checkmark$ \\
\hline $\begin{array}{c}\text { New } \\
\text { Zealand } \\
(2016)\end{array}$ & & $\checkmark$ & $\checkmark$ & $\checkmark$ & & $\checkmark$ \\
\hline $\begin{array}{l}\text { Singapore } \\
(2001)\end{array}$ & $\checkmark$ & & $\checkmark$ & & & $\checkmark$ \\
\hline
\end{tabular}

Sources: Asia-Pacific Economic Cooperation Secretariat (APEC) (2017)

\section{Comparison in monetary measure}

The listed countries provide various financial incentives to consumers, such as direct subsidy during the purchase or fiscal incentives such as tax exemption and reduction (refer Table 6). Based on our understanding, Malaysia only provides a reduction in road tax, and no direct subsidy is provided. Other 
incentives are almost the same across countries, as access to designated public parking, high occupancy vehicle land, and green licence plates. At the same time, significant differences exist in the levels and forms that each government provides to enhance the adoption of NEVs in their countries.

\section{Comparison in technology, infrastructure, and human capital development measures}

In terms of support for the charging station, the countries except Canada have some programmes to support the charging infrastructure. In particular, Korea has a unique concept where their energy provider, Korea Electric Power Co., has set up a charging tariff for electric vehicles that provides the charging company with almost the same value as the initial electricity cost. The charging service will then provide consumers with a tariff to subsidise the charger's original deployment and operating costs. The initiative will encourage the set-up of more charging providers. Car manufacturing countries like the USA, China, Japan, and Korea invest heavily in developing new technology. Collaboration between several educational research institutions and government bodies help to push innovation forward in these countries.

In China, the 863 Programme is crucial for the promotion of strategic research and development. Two billion yuan is spent maintaining the research effort involving Chinese car manufacturers, universities, and research institutions. The Chinese government also launched China New Energy Vehicle Development Projects supporting NEV industry development from 2011 to 2020. Japan had been supporting research and development for BPEVs since 1971 and are now focusing on the standardisation project for the future fuel cell vehicle market. The Korean government focuses on the Green Car Roadmap, which includes a collaboration of 44 institutes, including Hyundai Motor, with a government contribution of over 70 billion KRW. The USA government spends $\$ 1.5$ billion to assist manufacturers in manufacturing high-efficiency batteries and their components and $\$ 500$ million in developing other components needed for BEVs and other vital components. Malaysia is also a car manufacturing country, but Malaysia relies heavily on technology transfers from other international car manufacturers to boost the local industry (Khan, 2019). Under NAP 2014, there are incentives to attract FDIs and support local original equipment manufacturers and vendors.

\section{Comparison in legislation/traffic regulations}

As mentioned in section 3.2.3, Malaysia has some tax law mentioned in NAP 2014 and NEMB 2015, but none has been materialised. Out of the eight countries mentioned in the APEC automotive report, only the USA has a zero-emission law. The zero-emission mandate is specific clauses in the Clean Air Act (section 177) that allow states to either obey federal automobile emission regulations or enforce California's emission regulations. California expects $15 \%$ of new vehicle sales in 2025 to be zeroemission cars.

Table 6: Some of the financial incentive in APEC country

\begin{tabular}{ccc}
\hline & \multicolumn{1}{c}{ United States of America } \\
\hline Fiscal & $\bullet$ & BEV and PHEV were eligible for a federal income tax incentive of up to \\
incentives & $\$ 7,500$ in or after 2010. \\
& - $\begin{array}{l}\text { Policies at the state level. For example, tax exemptions, payment } \\
\text { bonuses, discounts for insurance and parking incentives. }\end{array}$ \\
\hline & China \\
\hline Direct subsidy & - & Up to $\$ 7,737$ of central government subsidies for PHEV and $\$ 9,284$ for \\
& BEV. \\
& - & Several local authorities have supplementary subsidies. \\
\hline Fiscal & Australia \\
\hline incentives & Discounts for registration and stamping duties. \\
\hline & \\
\hline
\end{tabular}


DOI: https://doi.org/10.47405/mjssh.v6i3.715

\begin{tabular}{|c|c|}
\hline \multicolumn{2}{|c|}{ Direct subsidy • Incentive program for vehicle purchases (up to $\$ 8,500$ ). } \\
\hline \multicolumn{2}{|c|}{ Japan } \\
\hline Direct subsidy & $\begin{array}{l}\text { - One-time BEV bonus and other qualified fuel-efficient vehicles (based } \\
\text { on the gasoline car price difference). The bonus is limited to } \$ 7,971 \\
\text { - Fifty per cent of the exorbitant price of the vehicle will be subsidised. } \\
\text { - Some local authorities and other agencies support additional subsidies. }\end{array}$ \\
\hline \multicolumn{2}{|r|}{ Korea } \\
\hline Direct subsidy & $\begin{array}{l}\text { With a rebate of } \$ 1,364 \text {, Ray EV was funded while charging } \\
\text { infrastructure at } \$ 800 \text {. } \\
\text { - A rebate of } \$ 1,909 \text { subsidised the cost of low-speed EVs, while charging } \\
\text { station infrastructure } \$ 525 \text {. }\end{array}$ \\
\hline $\begin{array}{c}\text { Fiscal } \\
\text { incentives }\end{array}$ & $\begin{array}{l}\text { The tax reduction on expenses such as individual consumption, } \\
\text { procurement and training up to } \$ 3,818 \text {. }\end{array}$ \\
\hline \multicolumn{2}{|r|}{ New Zealand } \\
\hline $\begin{array}{c}\text { Fiscal } \\
\text { incentives }\end{array}$ & $\begin{array}{l}\text { - Road user waiver about } \$ 600 \text { per year for private vehicles. } \\
\text { - Review Accident Compensation Corporation payments for BEV electric } \\
\text { plug-in. }\end{array}$ \\
\hline \multicolumn{2}{|r|}{ Singapore } \\
\hline $\begin{array}{c}\text { Fiscal } \\
\text { incentives }\end{array}$ & - Green car discount for NEVs equal to $40 \%$. \\
\hline
\end{tabular}

\section{Governmentpromotions and interventions}

To stimulate and promote the use of NEVs, some proactive governments had put enormous effort into promoting NEVs to the public. The Canadian government pledged that $20 \%$ of Ontario Public Service passenger vehicles purchased would be BEVs by 2020. The New Zealand government promoted EVs and bulk purchased EVs for their public and private sector fleets. The Chinese government initiated a promotion programme to stimulate the adoption of NEVs through 'Ten cities, thousand vehicles' programmes. It also pledged to convert government fleets to NEVs. Singapore runs a trial car-sharing programme as a promotion programme to boost EVs whereby the EV sharing programme will be made available in every Housing \& Development Board town by 2020.

\section{Summary of data analysis from an interview with experts}

All of the respondents agree that the current policy on EEVs needs to be revised and updated, especially concerning the carbon emission standards in the definition of EEV. The current classification focusses on curbing weight and fuel consumption, whereas the classification of EEVs should be enhanced based on carbon emission standards to better comply with an international standard. Most of the respondents mentioned that the price of BEVs, HEVs, and PHEVs needs to be reduced substantially to ensure mass acceptance. Direct subsidy and fiscal incentives targeted at consumers should be continued until production meets a specific number on the road; this ensures that businesses can reach economies of scale. Thus, to promote innovation, fiscal incentives can be given to local original equipment manufacturers to encourage their automotive market participation.

Table 7: Summary of suggested strategies from the panel of experts

\begin{tabular}{ccl}
\hline Variable & No. & \multicolumn{1}{c}{ Suggested strategies } \\
\hline $\begin{array}{c}\text { Direct } \\
\text { subsidies }\end{array}$ & 1. & $\begin{array}{l}\text { Allocate subsidies to promote a green lifestyle. } \\
\text { Purchase subsidy to reduce the price of BEVs until they hit a } \\
\text { particular economy of scale. }\end{array}$ \\
\hline
\end{tabular}


DOI: https://doi.org/10.47405/mjssh.v6i3.715

\begin{tabular}{|c|c|c|}
\hline $\begin{array}{r}\text { Fiscal } \\
\text { incentive }\end{array}$ & 2. & $\begin{array}{l}\text { An attractive incentive package to attract domestic investor and } \\
\text { support the whole EEV ecosystem. } \\
\text { A fiscal stimulus such as temporary tax exemption to encourage } \\
\text { and convince domestic investors is essential to reducing foreign } \\
\text { direct investment dependencies. }\end{array}$ \\
\hline $\begin{array}{l}\text { Infrastructur } \\
\text { al measures }\end{array}$ & 3. & $\begin{array}{l}\text { Setting up more local vendors for parts will help to reduce the } \\
\text { price of EEV. } \\
\text { The whole ecosystem must be in place - more charging station } \\
\text { and post-sale service centre for BEV, HEV, PHEV. } \\
\text { Encourage public-private partnerships to expand infrastructure } \\
\text { and networks. } \\
\text { The standard for charging facilities must comply with an } \\
\text { international standard. }\end{array}$ \\
\hline $\begin{array}{l}\text { Technologies } \\
\text { and Human } \\
\text { Capital } \\
\text { Development }\end{array}$ & $\begin{array}{l}3 . \\
4 .\end{array}$ & $\begin{array}{l}\text { To encourage more local manufacturer venturing to relevant } \\
\text { technology for EVs - focusing on critical components, for } \\
\text { example, battery pack or power train. } \\
\text { Labelling, certification (standardisation) of technology to comply } \\
\text { with environmental regulations and standards. } \\
\text { Develop technology that can withstand the tropical climate. } \\
\text { Reward innovation by providing more research \& development } \\
\text { grants. } \\
\text { The current workforce will benefit from professional certification } \\
\text { and competency skills development. }\end{array}$ \\
\hline $\begin{array}{l}\text { Legislation/ } \\
\text { Traffic } \\
\text { regulation }\end{array}$ & $\begin{array}{l}1 . \\
2 . \\
3 . \\
4 .\end{array}$ & $\begin{array}{l}\text { Clear long-term national aspiration/policy. } \\
\text { The tax law that ties in with the environmental pollution act. } \\
\text { Scrap policy should be introduced. } \\
\text { Introducing traffic regulation, such as a carbon tax or a vehicle } \\
\text { emission scheme. } \\
\text { The definition of EEV must be revised and updated. } \\
\text { A mandate by the government to support cleaner fuel with less } \\
\text { carbon emission. } \\
\text { Green labelling for a new vehicle. }\end{array}$ \\
\hline
\end{tabular}

Having local original equipment manufacturers producers will encourage more local assembly. The industry respondents wanted the government to have a clear aspiration on the automotive industry. Sound policy is crucial to support investors to decide on long-term investments as car manufacturing is a huge investment, and business must be viable in terms of business sense. Respondents from the ministry agree that there is a plan to impose traffic regulation, but its implementation would not be successful if the critical issue of the high price of certain EEVs is not resolved. Moreover, traffic regulation and legislation need to be materialised as they can be the enabler to increase the adoption of EEVs. EEVs should not be viewed as another variant on the market but must tie in with current legislation on environmental pollution, such as air pollution control. Some of the suggested strategies to enhance the current EEV policy are shown in Table 7.

Figure 5. A conceptual framework for better implementation of EEVs initiative in Malaysia 


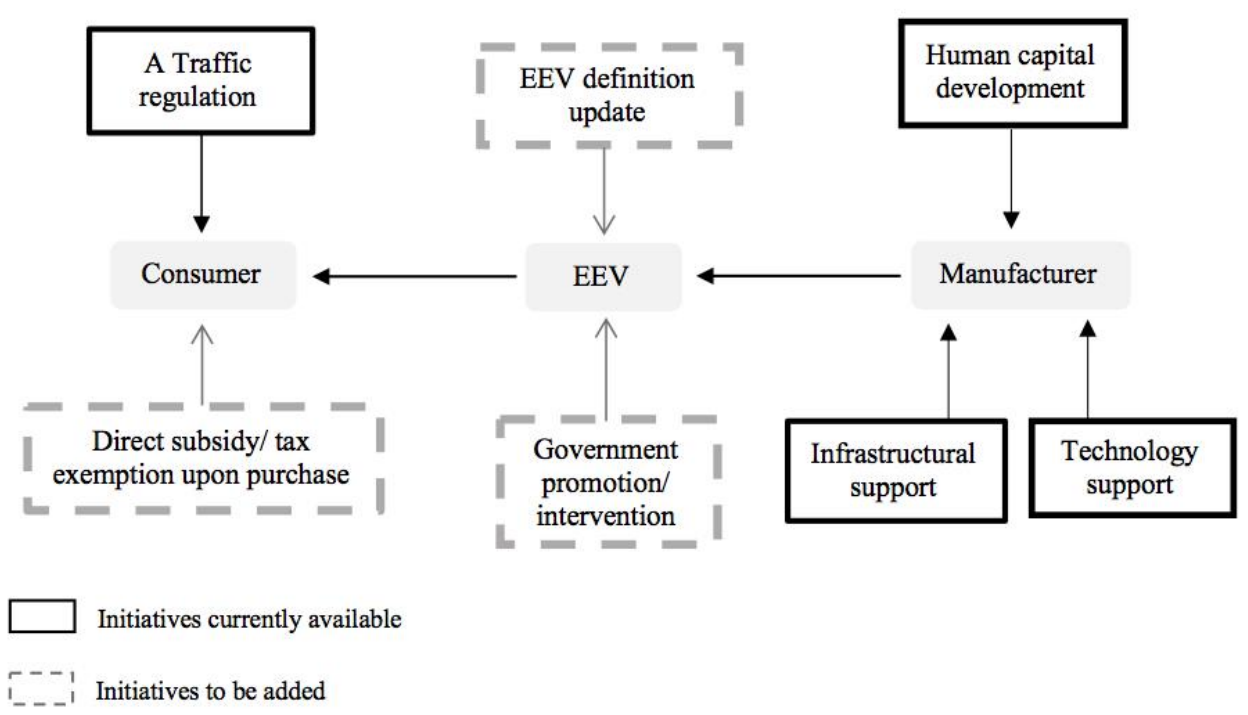

\section{Recommendations and Conclusion}

The need to reduce $\mathrm{CO} 2$ emissions from the transportation sector has been discussed globally. There is a need to live more sustainably and take mitigation measures to curb emissions that could impact global climate change significantly, where automakers have begun to minimise carbon emissions. The association between policy and ministry jurisdiction in Malaysia was explained and compared with other APEC member countries' implementation to offer insights into the current government policy. This study proposes a conceptual framework to improve the EEVs initiative's implementation in Malaysia. The integration between various agencies and market players is critical to determine the success and sustainability of EEVs implementation.

Based on the findings from both content analysis and interviews with experts, a conceptual framework for improved implementation of the EEVs initiative in Malaysia is proposed as per Figure 5. The existing definition for the carbon emission standard for the EEV definition is still a criterion. If this criterion is not revised, the export potential for local EEV products will face difficulties as international standards move towards cleaner fuel and variants. Direct subsidy or tax exemption upon purchases of EEVs should be given per citizen on a one-time basis. Furthermore, the Malaysian government needs to tighten requirements to qualify for excise tax deductions under the EEV programme; this aids in lowering the price of EEVs and create more volume to reach economies of scale. A one-time subsidy or tax exemption has less financial burden on the government but is an excellent tool to promote the adoption of EEVs. Taking an example from other countries, the Malaysian government should adopt EEVs in the government or public fleet, which is another way to promote EEVs while allowing the general public to become familiar with EEVs.

\section{References}

Adnan, N., M Vasant, P., Rahman, I., \& Noor, A. (2016). Adoption of Plug-in Hybrid Electric Vehicle among Malaysian Consumers. Industrial Engineering \& Management, 5(2). https://doi.org/10.4172/2169-0316.1000185

Asia-Pacific Economic Cooperation Secretariat (APEC). (2017). The Impact of Government Policy on Promoting New Energy Vehicles (NEVS): The Evidence in APEC Economies (Issue March). https://www.apec.org/Publications/2017/03/The-Impact-of-Government-Policy-on-PromotingNew-Energy-Vehicles-NEVs--The-Evidence-in-APEC-Economie

Bullard, N. (2019). Electric Car Price Tag Shrinks Along With Battery Cost. Bloomerg. https://www.bloomberg.com/opinion/articles/2019-04-12/electric-vehicle-battery-shrinks-and-sodoes-the-total-cost

Chong, C., Ni, W., Ma, L., Liu, P., \& Li, Z (2015). The use of energy in Malaysia: Tracing energy 
DOI: https://doi.org/10.47405/mjssh.v6i3.715

flows from primary source to end use. Energies, 8(4), 2828-2866. https://doi.org/10.3390/en8042828

Free Malaysia Today (FMT). (2018). EEV tax incentives only helping the rich so far. FMT News. https://www.freemalaysiatoday.com/category/leisure/2018/08/13/eev-tax-incentives-onlyhelping-the-rich-so-far/

Hasan-Basri, B., Mustafa, M. M., \& Bakar, N. (2019). Are Malaysian consumers willing to pay for Hybrod Cars'attributes? Jurnal Ekonomi Malaysia, 53(1). https://doi.org/10.17576/JEM-20195301-10

Ho, F. (2019). Top 15 Most Fuel Efficient Cars In Malaysia For Under RM100,000. https://www.imoney.my/articles/top-15-most-fuel-efficient-cars-for-under-rm100000

Hong, Y. H., Khan, N., \& Abdullah, M. M. (2013). The Determinants of Hybrid Vehicle Adoption: Malaysia Perspective. Australian Journal of Basic and Applied Sciences, 7(8), 447-454.

Khan, R. (2019). Time to open up the market for 3rd national car | Free Malaysia Today. Free Malaysia Today. https://www.freemalaysiatoday.com/category/opinion/2019/05/08/time-to-openup-the-market-for-3rd-national-car/

Lieven, T. (2015). Policy measures to promote electric mobility - A global perspective. Transportation Research Part A: Policy and Practice, 78-93. https://doi.org/10.1016/j.tra.2015.09.008

Lye, G. (2017). Perodua Bezza secures Frost \& Sullivan Malaysia's 2017 Car of the Year and Debut Car of the Year awards. Paultan.Org. https://paultan.org/2017/04/17/perodua-bezza-frostsullivan-malaysias-2017-car-of-the-year/

Lye, G. (2020). NAP 2014 report card - RM10 . 05 billion investments, $62 \%$ TIV EEV. Local News. https://paultan.org/2020/02/21/nap-2014-report-card-rm10-05-billion-investments-62-tiv-eevpenetration-rm58-7-billion-local-content/

Malaysia Automotive Robotics and IoT Institute (MARii). (2020). An overview of the NAP 2020: Directions and Strategies. http://www.marii.my/post/an-overview-of-the-nap-2020-directionsand-strategies

Malaysian Automotive Association (MAA). (2021). Summary of New Passenger \& Commercial Vehicles Registered in Malaysia For the Year 2010 to 2020. Sales \& Production Statistics. http://www.maa.org.my/statistics.html

Malaysian Green Technology and Climate Change Centre (MGTC). (2021). chargEV Malaysia Empowering Electric Mobility. https://chargev.chargev.my/

Ministry of Energy Green Technology and Water (KeTTHA). (2017). Green Technology Master Plan. https://www.pmo.gov.my/wp-content/uploads/2019/07/Green-Technology-Master-PlanMalaysia-2017-2030.pdf

Ministry of Energy Science Technology Environment and Climate Change (MESTECC). (2018). Malaysia Third National Communication and Second Biennial Update Report to the United Nations Framework Convention on Climate Change. In Minsitry of Energy, Science, Technology, Environment And Climate Change. https://www.mestecc.gov.my/web/documents/jqhRxaP3ff20SNzCaBfiyqiOdsLhuBa9Jyz5D0C_g Q0

Ministry of International Trade and Industry (MITI). (2014). National Automotive Policy (NAP) 2014. $\begin{array}{llllll}\text { In } & N A P & 2014 & \text { (Vol. } & 39, & \text { Issue }\end{array}$ ). http://dx.doi.org/10.1016/j.biochi.2015.03.025\%0Ahttp://dx.doi.org/10.1038/nature10402\%0Ahtt p://dx.doi.org/10.1038/nature21059\%0Ahttp://journal.stainkudus.ac.id/index.php/equilibrium/arti cle/view/1268/1127\%0Ahttp://dx.doi.org/10.1038/nrmicro2577\%0Ahttp://

Ministry of Natural Resources and Environment Malaysia (KeTSA). (2015). Malaysia's First Biennial Update Report submitted to the United Nations Framework Convention on Climate Change. https://unfccc.int/sites/default/files/resource/MALBUR1.pdf

Mock, P., \& Zifei, Y. (2014). Driving electrification: A global comparison of fiscal incentive policy for electric vehicles. In WhitePaper (Issue https://theicct.org/sites/default/files/publications/ICCT_EV-fiscal-incentives_20140506.pdf

Nie, Y., Ghamami, M., Zockaie, A., \& Xiao, F. (2016). Optimisation of incentive polices for plug-in electric vehicles. Transportation Research Part B: Methodological, 84, 103-123. https://doi.org/10.1016/j.trb.2015.12.011

Ong, H. C., Mahlia, T. M. I., \& Masjuki, H. H. (2011). A review on emissions and mitigation strategies for road transport in Malaysia. Renewable and Sustainable Energy Reviews, 15(8), 3516-3522. 
https://doi.org/10.1016/j.rser.2011.05.006

Pohl, H., \& Yarime, M. (2012). Integrating innovation system and management concepts: The development of electric and hybrid electric vehicles in Japan. Technological Forecasting and Social Change, 79(8), 1431-1446. https://doi.org/10.1016/j.techfore.2012.04.012

Ritchie, H., \& Roser, M. (2017). $\mathrm{CO}_{2}$ and Greenhouse Gas Emissions. Our World in Data. Our World in Data. https://ourworldindata.org/co2-and-other-greenhouse-gas-emissions

Shukor, M. S. bin, Sulaimana, Z., Chin, T. A., \& Mas'od, A. (2017). Malaysia Automotive Industry: Moving Toward Energy Efficient Vehicle Era. Social Science Postgraduate International Seminar (SSPIS) 2017, 1(1), 562-658.

Sierzchula, W., Bakker, S., Maat, K., \& Van Wee, B. (2014). The influence of financial incentives and other socio-economic factors on electric vehicle adoption. Energy Policy. https://doi.org/10.1016/j.enpol.2014.01.043

Statista. (2019). Energy efficient vehicle penetration rate in Malaysia 2018-2019. Statista. https://www.statista.com/statistics/982197/malaysia-energy-efficient-vehicle-penetrationrate/\#: :text=This statistic represents the penetration,penetration rate reached 62 percent.

Tan, S. (2019). 50 \% Road Tax Reduction For And Hybrid Cars Announced. World of Buzz. https://worldofbuzz.com/50-road-tax-reduction-for-electric-and-hybrid-cars-announced-by-govt/

Tie, S. F., \& Tan, C. W. (2013). A review of energy sources and energy management system in electric vehicles. Renewable and Sustainable Energy Reviews, 20, 82-102. https://doi.org/10.1016/j.rser.2012.11.077

Yusof, A. (2020). Sparking Malaysia's next EEV journey. New Straits Times Press. https://www.nst.com.my/business/2020/01/560303/sparking-malaysias-next-eev-journey

Zhang, Xiang, Bai, X., \& Shang, J. (2018). Is subsidised electric vehicles adoption sustainable: Consumers' perceptions and motivation toward incentive policies, environmental benefits, and risks. Journal of Cleaner Production, 192, 71-79. https://doi.org/10.1016/j.jclepro.2018.04.252

Zhang, Xingping, Xie, J., Rao, R., \& Liang, Y. (2014). Policy incentives for the adoption of electric vehicles across countries. Sustainability (Switzerland). https://doi.org/10.3390/su6118056 